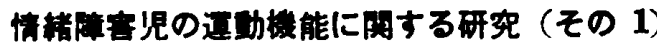

チャ1ルドガイダンスセンター

○伊藤 洋子, 武田 慎二 矢内 伸夫

東京理科大学 正 木 侓 雄 日本体育大学 伊藤孝

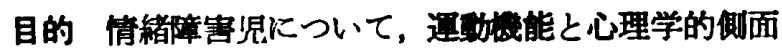
との関係を究明しょ5とした。

対象及び方法 被験者は渪 5 才〜12才までの 児直 40 名，その5ち情緒障害児30名である．遇物璣能の测定に は狩野式運動能発至梌查を用い，性格判定には，M J 式ハーソナリティーインベントリーの尺度を利用して锶

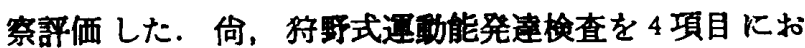
けるA平衡性，B全身の協调，C手指の協調，D分離模 做運動の難易度及び種目数の異りを好理する為に，1961 年 5 月に正木らが実施した東京千代田区九段幼稚園及び 九段小学校の児童 275 名の狩矛式の検査結果をるとにし て イースコフ表を成作した。

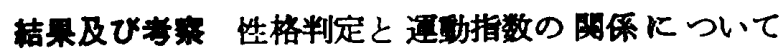
は，通䖝指数が90以上であった者の70\%が性格面であ正 常と判定され，これに対して，通動指数が69以下であっ た者の 全員が性格面で非常に問题と判定されている.
又, 運動機能に於て コア45以上の值を示す者の71\%が性格面です正常と判定 されているのに対し，4 項目の5ち3〜全項目がT-スコ ア44以下の值を持つ者では性格面で正常と判定された者 はひとりるなく，その87.5\%が性格面で非常に問題あり と判定されている，さらに 4 項目の5ち，いずれか 1 項 目ですTースコア44 以下の値を示す者は，4 項目共にTスュフ45以上の者に比して, 自信久如，抑 5 つ, 不安

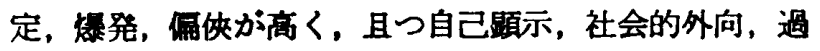
活動，従属が低いという性格特嚾を表わしている，次に 18名について，治歷により政善された性格面と向上した 運動機能との関係を調へててた。 その結果，A，B，C，D の各項目が伸びた者の 8 割以上が性格面におけり行動活 動面か改善され，又，全身の協調と分離模做運動の項目 について伸びた者では，同時に内向内省面にも6 割以上 の改善が見られる.

以上，今回の研究では，運動面で正常なものは，性格 面でも正常なるのが多く，反対に運動機能面で劣る者の 多くは，性格的に問通のある者が多い結果を得た。 ま た，活较行轩面，内向内省面という性格は殊に遇動譏能 とのつながりが密接であると思われる。

\section{6. 体市・スポーツに対する等度について} 大阪信爱女学院短期大学 $\mathrm{O}$ 皇 中 大阪教育大学柏原健三

(1) 目的 体青における学署の効果を高めるためには 学生, 生徒の日頁のスポーツや授莱に対する考え方（拈 度）を知ることは，指蒀上の一凸の手がかりになると思 われる.そこで中，高，大学生の考え方を考察し特に今 回は女子大学生の䈍度を考察した。

（2）方法 1）対象 中学生 1332 名, 高校生 1934 名, 大学生 405 名とした，大学生女子は体育尃攻生 43 名， 短大生 A（普通一股）200名，短大生 B（体育活動の少 ない宗教柔大学）112名，2）誏亘方法 体育・スポーツ に対する然度についての50 項目よりなる調查票により 実施した.これは “Research Quarterly”にあげている あのを孝考にした．3）結果の処理方法 (1)項目別，各 校各学年，男女別に 集計し百分率を算出した．（2)中学 生, 高校生, 大学生について項目别の 平均值を算出し た. (2大学生については各項目を，i）身体的な面，ii） 社会的な面，iii）価值的な面，iv）技能的な面，v）そ の他に分類し比梌討を行った。.

（3）赫来 (1)この調查にみられる佰向としては一般的 に中，高，大学を通して樌在的な（㠺定的）等度を示し
ている. (2大学生で表の上らな結果である. 技薪する と 26 項目「体育の時間は毎日あってもよいと思5」に

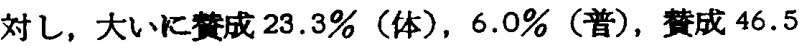
$\%$ (体)，14.0\% (普)，わからない $11.6 \%$ (体)，14.8 $\%$ (普)，反対 $18.6 \%$ (体)，49.0\% (普)，非常に反対 $0 \%$ (体)，16.2\% (普)とい5結果であり，一坄学生は 滑厓的热度である.

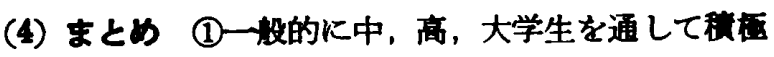
的な（肯定的）憼度を示している.

(2)女子大学生では社会的，価值的，技能的な面では同 じ㑯向であるが，興味の面では体育専攻生に比し一般学 生は滑厔的管度である。

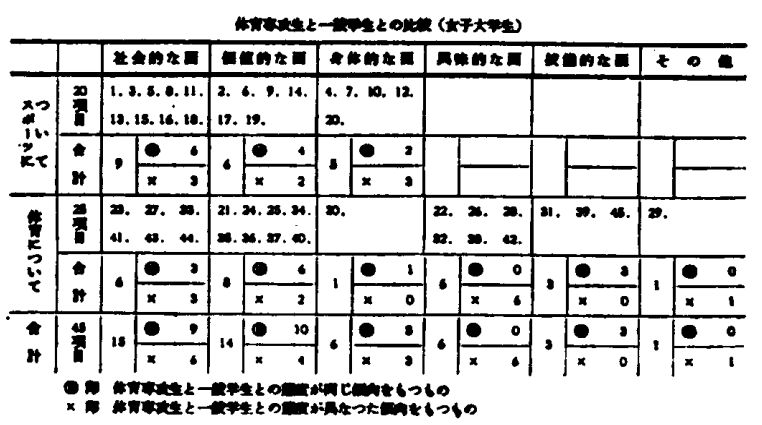

